\begin{tabular}{|c|l|}
\hline Title & $\begin{array}{l}\text { Non-Invasive Genetic Identification of the Red Fox Vul pes vul pes in the Shiretoko National Park, Eastern Hokkaido, } \\
\text { Japan }\end{array}$ \\
\hline Author(s) & Oishi, Takuya; Uraguchi, Kohji; Masuda, Ryuichi \\
\hline Citation & $\begin{array}{l}\text { Mammal Study, 35(3), 201-207 } \\
\text { https://doi.org/10.3106/041.035.0306 }\end{array}$ \\
\hline Issue Date & 2010-09 \\
\hline Doc URL & http://hdl.handle.net/2115/48768 \\
\hline Type & article \\
\hline File Information & MS35-3_201-207.pdf \\
\hline
\end{tabular}

Instructions for use 


\title{
Non-invasive genetic identification of the red fox Vulpes vulpes in the Shiretoko National Park, eastern Hokkaido, Japan
}

\author{
Takuya Oishi ${ }^{1}$, Kohji Uraguchi ${ }^{2}$ and Ryuichi Masuda ${ }^{1, *}$ \\ ${ }^{1}$ Department of Natural History Sciences, Graduate School of Science, Hokkaido University, Sapporo 060-0810, Japan \\ ${ }^{2}$ Hokkaido Institute of Public Health, Sapporo 060-0819, Japan
}

\begin{abstract}
In order to assess the genetic usefulness of feces that were obtained from field, we conducted genetic identification by microsatellite analysis on fecal samples of the red fox (Vulpes vulpes) collected in the Shiretoko National Park, Hokkaido. Consequently, 59 fecal samples resulted in 22 as the minimum number of individuals. The cumulative $P_{\text {(ID)sibs }}$ in the 22 samples was less than 0.01 . Two pairs of fecal samples having the identical genotypes $\left(P_{(\mathrm{ID}) \text { sibs }}<0.01\right)$ were considered to be dropped by the same foxes, and the distribution of these feces was almost overlapped with the home range of one fox, revealed by a previous study. Although few reports had revealed the absolute number of red foxes in field, the present study showed that the genetic analysis of their feces is useful for estimating a presumable number of individuals in the area. However, the lower genotyping success rates (23.3-69.8\%) and genotyping reproducibility (53.5-88.4\%) indicate the difficulty of genetic analysis by using these fecal samples. In order to improve the efficiency of the analysis, it may be effective to select and use a marker set which has smaller allele sizes, because the genotyping success rates and reproducibility increased when the average allele size decreased.
\end{abstract}

Key words: feces, genetic identification, non-invasive method, Vulpes vulpes.

The Shiretoko National Park in eastern Hokkaido, Japan (Fig. 1a) covers an area of 38,633 ha, and the primitive forests are still conserved in the park. The vertebrates such as the brown bear (Ursus arctos), steller's sea-eagle (Haliaeetus pelagicus) and Blakiston's fish owl (Ketupa blakistoni) and marine animals such as the chum salmon (Oncorhynchus keta), killer whale (Orcinus orca), sperm whale (Physeter macrocephalus), harbor seal (Phoca vitulina) consist of the specific food chain system. For conservation of the richness of the ecosystems and biodiversity, this area was registered as the World Nature Heritage in 2005 by the International Union for the Conservation of Nature and Natural Resources (IUCN).

The red fox (Vulpes vulpes) is also one of the mammals inhabiting this park. It plays an important role in the ecosystem as carnivore, and is an ecologically wellstudied mammal in the Shiretoko National Park. Tsukada and Nonaka (1996) investigated the food habit of the red fox in the park, and revealed the utilization of provisions by human as secondary food supply. Tsukada (1997a) carried out the radio tracking of the red fox there, and reported that its home ranges were fluctuated with the seasonal resources and the human feeding. Tsukada et al. (1999) conducted the spotlight census in order to examine changes of the fox population size, and suggested the significant reduction of the population caused by sarcoptic mange. In addition, the red fox in Hokkaido carries the tapeworm Echinococcus multilocularis causing serious zoonosis, alveolar echinococcosis (Oku and Kamiya 2003). Nonaka et al. (1998) reported E. multilocularis infection in red foxes in Shiretoko by coproantigen detection, and recently the Hokkaido Institute of Public Health investigated the infection of E. multilocularis by egg examination with DNA identification about fox feces collected in the same area. The coproantigen or DNA positive rate based on the number of each positive feces is not the precise infection rate of the parasite among foxes, because of double-counting of feces from the same individual. However, the genetic identification technique in addition to the above method may lead to giving us the precise infection rate among foxes.

In the present study, to assess the usability of the fox feces that had been collected for examination of $E$.

*To whom correspondence should be addressed. E-mail: masudary@ees.hokudai.ac.jp 
multilocularis, we conducted genetic identification of individuals by microsatellite analysis on the feces. In non-invasive DNA analysis, in general, feces are newly and systematically collected only for the purpose of genetic study (e.g. Banks et al. 2002; Lucchini et al. 2002; Flagstad et al. 2004; Bellemain et al. 2005; Piggott et al. 2006). For example, Shimatani et al. (2008, 2010) analyzed DNA of fecal samples younger than 24 hours, which were collected from field everyday in one sampling period. These studies above have successfully resulted in estimation of the population size, sex ratio, dispersal and relatedness. Because animal feces have been used for various purposes such as analyses of food habits, infection rates of parasite, estrous cyclicity, etc. (e.g. Tsukada 1997b; Nonaka et al.1998; Putoranto et al. 2007), if such feces already used and stored at laboratory for the above purposes are usable for genetic analysis, the non-invasive samples can bring more information to wildlife researches. By applying the fecal DNA analysis to the red fox feces, it will be also possible to noninvasively examine the ecological aspects of the red fox at the park. Moreover, the genetic identification technique would give us the precise infection rate of parasites among foxes. From these viewpoints, it is significant to conduct non-invasive genetic identification analysis on feces of the red fox.

\section{Materials and methods}

\section{Sample collection and DNA extraction}

The Hokkaido Institute of Public Health investigated fox feces in the Shiretoko National Park in 2007 (Fig. 1a). All fox feces were collected from both road shoulders along the Prefectural Route 93 within $8 \mathrm{~km}$ length (Fig. 1b) and examined the egg of E. multilocularis. In the present study, we used 59 fecal samples that had been collected and stored after the egg examination of $E$. multilocularis by the Hokkaido Institute of Public Health. The fecal samplings were conducted three times: late May, July-August, and early October of 2007. Because a fecal sampling was also conducted early October of 2006, the feces analyzed in the present study could be dropped in less than eight months. Based on morphological observation, fecal conditions were categorized arbitrarily as "Dried and whitened", "Dried", "Usual", "Fresher", and "Fresh and wet". In order to inactivate tape worm eggs and prevent echinococcosis infection, the feces were carefully put into polypropylene conical tubes in field, and then incubated at $70^{\circ} \mathrm{C}$ for three days at laboratory. Then, the fecal samples were preserved at $4^{\circ} \mathrm{C}$ until DNA extraction. Total DNA was extracted from $0.3 \mathrm{~g}$ in wet weight of each fecal sample by using the QIAamp DNA Stool Mini Kit (QIAGEN). As positive control, DNA extracted from the fox muscle tissues by using the DNA Tissue Kit (QIAGEN) was used. The total volume $(200 \mu \mathrm{l})$ of the DNA solution was stored at $4^{\circ} \mathrm{C}$.

\section{PCR methods}

In order to confirm whether the fecal samples are of the red fox, polymerase chain reaction (PCR) was performed with the primers specific to the red fox mitochondrial DNA (mtDNA) control region, using the method of Shimatani et al. (2008). Because mtDNA is more easily

(a)

(b)

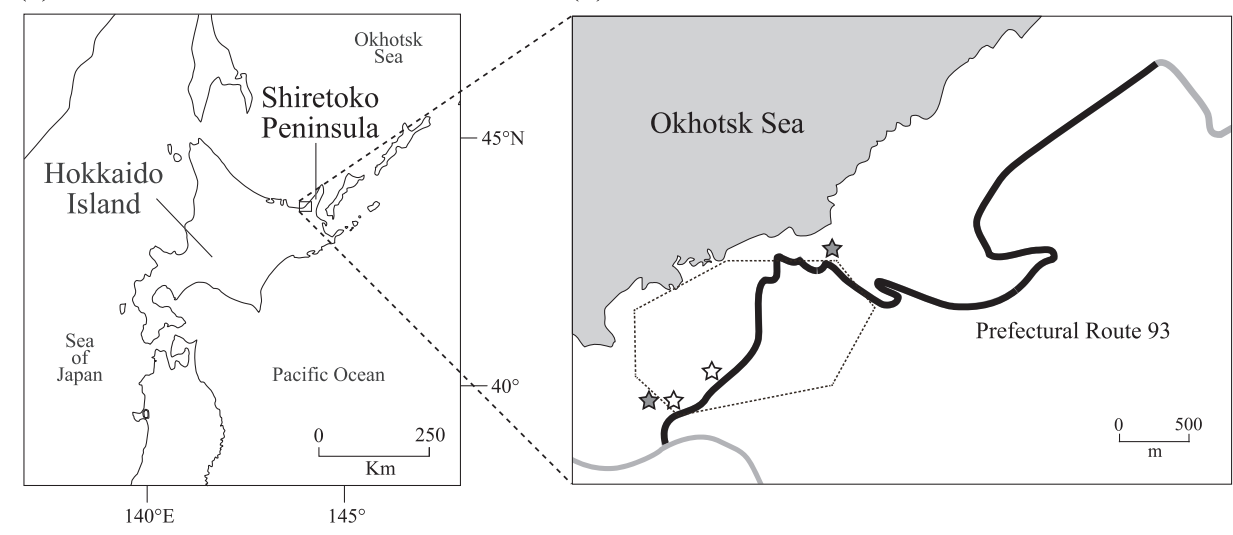

Fig. 1. (a) Location of the Shiretoko Peninsula on the Hokkaido Island. (b) The study area along Prefectural Route 93 in the Shiretoko Peninsula. The black line indicates the sampling area on the Route 93. The two open stars and two closed stars indicate the distribution of fecal samples which were consider to be dropped by the same foxes having the identical genotypes, respectively. Their genotypes are shown in Table 3 . The areas closed by broken lines are the home ranges of one red fox revealed by Tsukada (1997a). 
Table 1. Basic information of each microsatellite locus in the red fox

\begin{tabular}{cccccc}
\hline Locus & Allele size (bp) & Mean size (bp) & Number of alleles & $\begin{array}{c}\text { Genotyping } \\
\text { success rate (\%) }\end{array}$ & $\begin{array}{c}\text { Genotyping } \\
\text { reproducibility (\%) }\end{array}$ \\
\hline DB1 & $133-152$ & 138.1 & 6 & 51.2 & 55.8 \\
DB3 & $125-129$ & 126.7 & 3 & 51.2 & 53.5 \\
DB4 & $111-135$ & 116.5 & 5 & 51.2 & 55.8 \\
DB6 & $106-112$ & 108.4 & 3 & 37.2 & 67.4 \\
V142 & $136-160$ & 147.1 & 6 & 23.3 & 58.1 \\
V374 & $100-113$ & 106.3 & 4 & 46.5 & 72.1 \\
V402 & $83-97$ & 86.7 & 6 & 69.8 & 88.4 \\
V468 & $84-94$ & 89.1 & 4 & 65.1 & 74.4 \\
\hline
\end{tabular}

PCR-amplified from fecal samples than nuclear DNA (Birky et al. 1989), for the micosatellite analysis, we used only the feces, in which mtDNA was successfully amplified. In order to avoid genotyping errors by a low quality of fecal DNA, PCR amplifications and microsatellite genotyping were carried out three times per locus per sample. Then, we chose allele bands that appeared two times or more for genotype. For each sample, 12 microsatellite loci were amplified using the following primers; DB1, DB3, DB4 and DB6 (Holmes et al. 1993); C213 (Ostrander et al. 1993); V142, V374, V402, V468, V502, V602 and V622 (Wandeler and Funk 2006). The PCR mixture of a total volume of $10.0 \mu \mathrm{l}$ consisted of 1.0 $\mu 1$ of $10 \times$ PCR buffer, $0.8 \mu 1$ of dNTP mixture $(2.5 \mathrm{mM})$, $0.3 \mu \mathrm{l}$ of the primer above $(5 \mathrm{pmol} / \mu \mathrm{l}), 0.1 \mu \mathrm{l}$ of $\mathrm{rTaq}$ DNA polymerase ( 5 units/ $\mu 1$ : TAKARA), $6.5 \mu$ of distilled water and $1.0 \mu \mathrm{l}$ of each sample extract.

The PCR amplification was started with denaturing $94^{\circ} \mathrm{C}$ for $3 \mathrm{~min}$, then $30-40$ cycles of amplification were performed with the following programs using a DNA thermal cycler (TAKARA TP600): denaturing $94^{\circ} \mathrm{C}$ for $1 \mathrm{~min}$; annealing $52-60^{\circ} \mathrm{C}$ for $1 \mathrm{~min}$; extension $72^{\circ} \mathrm{C}$ for $1 \mathrm{~min}$, and reaction was completed at $72^{\circ} \mathrm{C}$ for $10 \mathrm{~min}$. Before sizing microsatellite alleles, $2.5 \mu \mathrm{l}$ of the Bromophenol blue loading solution (PROMEGA) were added to $2.5 \mu \mathrm{l}$ of each PCR product, denatured at $95^{\circ} \mathrm{C}$ for $2 \mathrm{~min}$, and chilled immediately on ice for $3 \mathrm{~min}$. Then, we applied the products to an autosequencer HITACHI SQ-5500L, and determined molecular sizes of microsatellite alleles using the computer software FRAGLYS 3 (Hitachi). Because no clear results of four loci (C213, V502, V602 and V622) were obtained, these loci were excluded in the subsequent analysis.

\section{Statistical analyses}

Allele fragment size ranges, average allele sizes, the number of alleles, and genotyping success rates of each locus were counted. The genotyping reproducibility was calculated as rates of samples that had the finally decided genotypes same as the result in the first analysis of three genotypings. The fecal conditions were compared with success rates of microsatellite genotyping and mtDNA amplification rates.

The minimum number of individuals was estimated by comparing the genotypes. After excluding all the samples that were not identified as unique individuals, in order to evaluate whether the loci used were effective to identify individuals, the probability of a genotypic match $\left(P_{(\mathrm{ID})}\right)$ was estimated by GIMLET version 1.3.2 (Valière 2002).

\section{Results}

In the present study, 43 of 59 samples were identified as fox feces by the mtDNA analysis. Basic information of each locus was shown in Table 1. All allele fragment sizes were less than $200 \mathrm{bp}$, and allele sizes of loci V402 and V468 were less than $100 \mathrm{bp}$. The number of alleles ranged from three to six through all the loci examined. The genotyping success rate was the lowest $(23.3 \%)$ at V142, and the highest (69.8\%) at V402. The genotyping reproducibility was the lowest $(53.5 \%)$ at DB3, and the highest (88.4\%) at V402. The genotyping success rate and reproducibility at each locus decreased when the average allele size increased (Figs. 2a, b).

There were no clear differences in genotyping success rates among condition levels of fecal samples (Table 2). In "Older feces" consisting of "Dried" and "Dried and whitened", the number of genotyped locus per sample was 4.21 and success rate of mtDNA analysis was $77.8 \%$, whereas those values in Fresher feces consisting of "Fresh and wet", "Fresh" and "Usual" were 3.96 and $68.3 \%$, respectively (Table 2 ).

The genotyping results of all fecal samples showed 
Table 2. Conditions of feces in field and PCR success rates

\begin{tabular}{lccccc}
\hline \multicolumn{1}{c}{ Condition } & $\begin{array}{c}\text { Number of } \\
\text { samples }\end{array}$ & $\begin{array}{c}\text { Samples succeded in } \\
\text { mtDNA analysis }\end{array}$ & $\begin{array}{c}\text { Genotyped } \\
\text { microsatellite loci }\end{array}$ & $\begin{array}{c}\text { Genotyped loci/ } \\
\text { sample analysed }\end{array}$ & $\begin{array}{c}\text { MtDNA } \\
\text { amplification rate } \\
(\%)\end{array}$ \\
\hline 1. Fresh and wet & 3 & 2 & 1 & 0.50 & 66.67 \\
2. Fresher & 2 & 1 & 6 & 6.00 & 50.00 \\
3. Usual & 36 & 25 & 104 & 4.16 & 69.44 \\
4. Dried & 7 & 6 & 27 & 4.50 & 85.71 \\
5. Dried and whitened & 11 & 8 & 32 & 4.00 & 72.73 \\
\hline Fresher $(1+2+3)$ & 41 & 28 & 111 & 3.96 & 68.29 \\
Older $(4+5)$ & 18 & 14 & 59 & 4.21 & 77.78 \\
\hline Total & 59 & 43 & 170 & 3.95 & 72.88 \\
\hline
\end{tabular}

a)

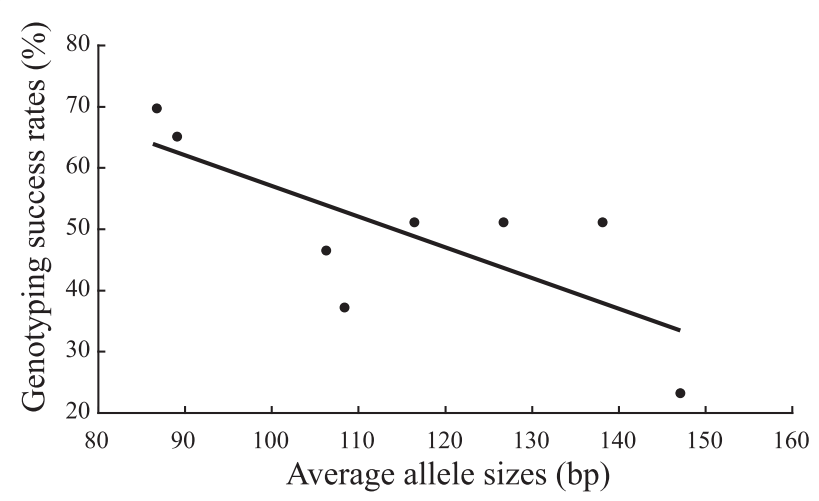

b)

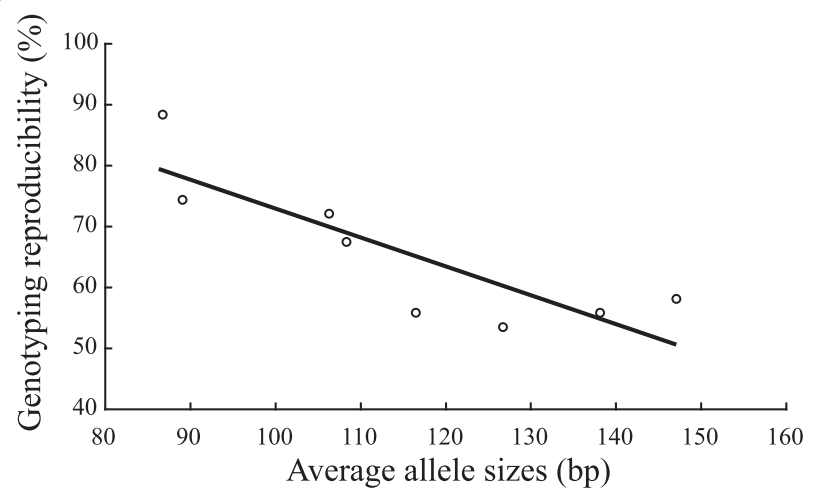

Fig. 2. (a) The relationships between genotyping success rates and average allele sizes, and (b) those between genotyping reproducibility and average allele sizes. The approximate lines were drown by Microsoft Excel X.

that the minimum number of individuals was 22 (Table 3 ). There were two pairs of fecal samples, which were considered to have the identical genotypes $\left(P_{(\mathrm{ID}) \text { sibs }}<0.01\right)$ (Table 3 and Fig. 1b). Cumulative $P_{(\text {(D) }) \text { sibs }}$ in the 22 samples was less than 0.01 at the 7th locus (Fig. 3). In all possible combinations of seven in the eight loci, cumulative $P_{(\mathrm{ID}) \text { sibs }}$ values were also estimated to be less than 0.01 .

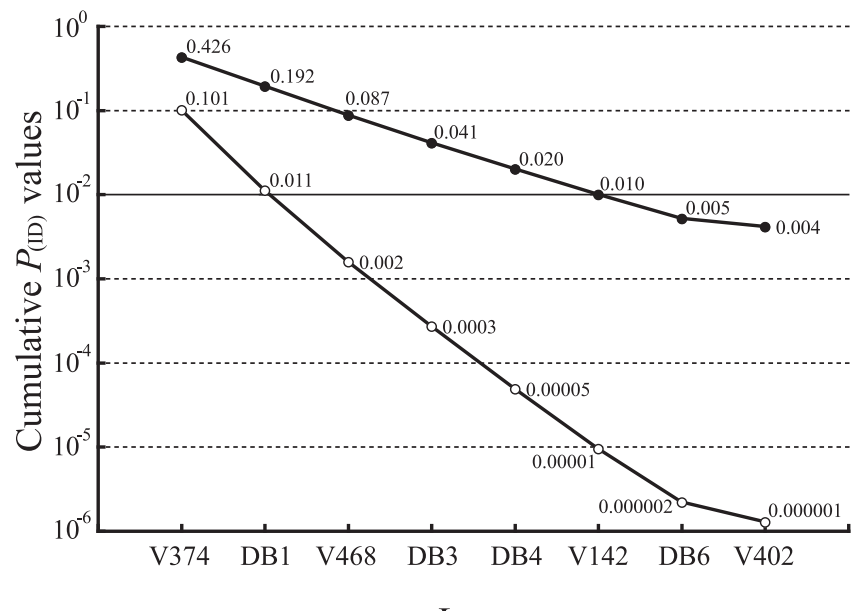

Locus

Fig. 3. Logarithmic plots of cumulative $P_{\text {(ID)unbiased }}$ (open circles) and $P_{\text {(ID)sibs }}$ values (closed circles).

\section{Discussion}

The present study, using fecal samples collected for the purposes except genetic analysis, demonstrated that at least 22 individuals occurred in the sampling area of the Shretoko Peninsula in the sampling period (spring to autumn of 2007). Although there has been few report on the absolute number of individuals of the red fox in Japan, Nonaka et al. (1998) reported that 3-4 families have their distinct territories along the road in this study area. If one family consists of two adults (male and female) and an average of 3.5 cubs (Tsukada 1997b), a total of 16.5-22 individuals occur along the road. Actually, there might be additional individuals such as helpers (Macdonald 1979, Suzuki et al. 1983, Tsukada 1997c) and itinerants (Tsukada 1997c) in this area, and consequently the result of this analysis that a minimum of 22 individuals occurred in the sampling area is reasonable. 
Table 3. Results of genetic identification of individuals

\begin{tabular}{|c|c|c|c|c|c|c|c|c|c|}
\hline \multirow{2}{*}{$\begin{array}{l}\text { Sample } \\
\text { code }\end{array}$} & \multicolumn{9}{|c|}{ Microsatellite loci } \\
\hline & DB1 & DB3 & DB4 & DB6 & V142 & V374 & V402 & V468 & \\
\hline S-07-29 & AA & AA & $\mathrm{CE}$ & AA & $\mathrm{DD}$ & $\mathrm{BC}$ & $\mathrm{BB}$ & $\mathrm{AC}$ & \\
\hline S-07-15 & AA & $\mathrm{AC}$ & $\mathrm{CE}$ & $\mathrm{AB}$ & $\mathrm{DD}$ & $\mathrm{BC}$ & $\mathrm{BB}$ & $\mathrm{AC}$ & \\
\hline S-07-23 & $\mathrm{AE}$ & AA & $\mathrm{CC}$ & BB & $\mathrm{BD}$ & $\mathrm{CC}$ & BB & $\mathrm{BC}$ & is \\
\hline S-07-17 & $\mathrm{EF}$ & BB & BB & $\mathrm{AC}$ & $\mathrm{BD}$ & $\mathrm{BC}$ & BB & $\mathrm{BC}$ & $\star$ \\
\hline S-07-3 & $\mathrm{AB}$ & $\mathrm{AC}$ & BB & BB & - & $\mathrm{AD}$ & BB & $\mathrm{BD}$ & \\
\hline S-07-59 & $\mathrm{AF}$ & $\mathrm{AC}$ & $\mathrm{CC}$ & $\mathrm{AB}$ & - & $\mathrm{BC}$ & $\mathrm{BD}$ & $\mathrm{BC}$ & \\
\hline S-07-11 & $\mathrm{AF}$ & $\mathrm{AC}$ & $\mathrm{CE}$ & $\mathrm{AB}$ & - & $\mathrm{BB}$ & $\mathrm{BD}$ & $\mathrm{AB}$ & \\
\hline S-07-99 & $\mathrm{CC}$ & $\mathrm{AC}$ & $\mathrm{BC}$ & $\mathrm{AB}$ & - & $\mathrm{AB}$ & BB & BB & \\
\hline S-07-77 & - & $\mathrm{BB}$ & $\mathrm{BB}$ & $\mathrm{AC}$ & $\mathrm{BD}$ & $\mathrm{BC}$ & $\mathrm{BF}$ & $\mathrm{BC}$ & \\
\hline S-07-71 & AA & - & - & AA & $\mathrm{BE}$ & $\mathrm{BC}$ & BB & $\mathrm{BC}$ & \\
\hline S-07-60 & $\mathrm{AB}$ & $\mathrm{AC}$ & $\mathrm{BB}$ & - & - & AA & $\mathrm{BB}$ & $\mathrm{BB}$ & \\
\hline S-07-114 & $\mathrm{AE}$ & $\mathrm{CC}$ & $\mathrm{CC}$ & AA & - & - & BB & $\mathrm{BC}$ & \\
\hline S-07-85 & $\mathrm{AF}$ & $\mathrm{CC}$ & $\mathrm{CE}$ & - & - & BB & $\mathrm{BD}$ & $\mathrm{AB}$ & \\
\hline S-07-63 & $\mathrm{BD}$ & $\mathrm{AB}$ & $\mathrm{BB}$ & - & - & $\mathrm{AD}$ & $\mathrm{BB}$ & $\mathrm{BD}$ & \\
\hline S-07-16 & - & BB & $\mathrm{CC}$ & $\mathrm{AC}$ & - & AA & BB & $\mathrm{BC}$ & \\
\hline S-07-20 & AA & $\mathrm{AA}$ & - & - & - & $\mathrm{CC}$ & $\mathrm{BB}$ & $\mathrm{AC}$ & \\
\hline S-07-75 & $\mathrm{CC}$ & - & $\mathrm{CC}$ & - & - & DD & BB & $\mathrm{BC}$ & \\
\hline S-07-6 & - & AA & BB & - & $\mathrm{BF}$ & - & BB & $\mathrm{BD}$ & \\
\hline S-07-34 & AA & BB & $\mathrm{CC}$ & - & - & - & - & $\mathrm{CC}$ & \\
\hline S-07-36 & - & BB & DD & - & - & - & BB & $\mathrm{CC}$ & \\
\hline S-07-10 & - & BB & - & - & - & $\mathrm{BC}$ & $\mathrm{AB}$ & $\mathrm{BC}$ & \\
\hline S-07-89 & - & - & - & BB & - & - & BB & DD & \\
\hline S-07-25 & - & - & - & - & - & - & $\mathrm{BB}$ & $\mathrm{AC}$ & \\
\hline S- $-07-48$ & AA & - & - & - & - & - & - & - & \\
\hline S-07-116 & $\mathrm{AA}$ & - & - & AA & - & - & BB & - & \\
\hline S-07-18 & $\mathrm{AE}$ & AA & $\mathrm{CC}$ & BB & - & $\mathrm{CC}$ & BB & $\mathrm{BC}$ & ts \\
\hline S-07-9 & - & - & $\mathrm{CC}$ & - & - & - & BB & - & \\
\hline S-07-32 & $\mathrm{EF}$ & $\mathrm{BB}$ & $\mathrm{BB}$ & $\mathrm{AC}$ & $\mathrm{BD}$ & $\mathrm{BC}$ & $\mathrm{BB}$ & $\mathrm{BC}$ & $\star$ \\
\hline S-07-5 & - & - & - & - & $\mathrm{CC}$ & - & - & - & \\
\hline S-07-113 & - & - & - & - & - & BB & - & - & \\
\hline S-07-38 & - & - & - & - & - & - & BB & BB & \\
\hline S-07-79 & $\mathrm{CC}$ & - & - & - & - & - & - & - & \\
\hline S-07-45 & - & - & AA & - & - & - & - & - & \\
\hline S-07-80 & - & $\mathrm{CC}$ & - & - & - & - & - & - & \\
\hline S-07-30 & AA & - & - & - & - & - & $\mathrm{CC}$ & - & \\
\hline S-07-4 & - & - & - & - & - & - & $\mathrm{EE}$ & - & \\
\hline S-07-42 & - & - & - & - & AA & - & $\mathrm{BB}$ & $\mathrm{CC}$ & \\
\hline S-07-69 & - & - & - & - & - & - & - & DD & \\
\hline S-07-22 & - & - & - & - & - & - & - & - & \\
\hline S-07-67 & - & - & - & - & - & - & - & - & \\
\hline S-07-68 & - & - & - & - & - & - & - & - & \\
\hline S-07-88 & - & - & - & - & - & - & - & - & \\
\hline S-07-112 & - & - & - & - & - & - & - & - & \\
\hline
\end{tabular}

Each genotype was shown as a combination of alleles expressed as A-F. Samples were divided into two groups by the broken line. Because samples in the upper group have different genotypes at one or more loci from the others, they were considered as unique individuals. Samples in the lower group could not be identified as unique individuals. The two samples with the open stars and the different two with the closed stars are considered to have the same genotypes, respectively $\left(P_{(\mathrm{ID}) \mathrm{sibs}}<0.01\right)$
The distribution of the feces that were considered to have been dropped from different individuals having the identical genotypes $\left(P_{(\mathrm{ID}) \text { sibs }}<0.01\right)$ was almost overlapped with the home range of one fox revealed by Tsukada (1997a) (Fig. 1b). The $P_{(\mathrm{ID})}$ values of less than 0.01 is necessary for population size estimation (Mills et al. 2000), and such values in $P_{(\mathrm{ID}) \text { sibs }}$ were earned without DB6 and V402 in the present study (Fig. 3). Moreover, in all possible combinations of seven out of the eight loci, $P_{(\mathrm{ID}) \text { sibs }}$ values were estimated to be less than 0.01 . Therefore, the combinations of the above six loci or all the combination of seven out of eight loci were considered effective to distinguish the fox individuals at the Shiretoko National Park. The present study showed two pairs of fox feces having $P_{(\mathrm{ID}) \text { sibs }}$ values of less than 0.01 which are considered to be dropped by the same foxes (Table 3). Tsukada (1997a) reported that the average size of the fox's home range in this area was about 250 ha, constantly from May to October every year (Tsukada 1997a). Therefore, it is reasonable to consider that the distribution obtained by the fecal DNA analysis is not incongruent with the fox home range in Shiretoko. Increasing the number of samples would provide us more detailed structures of fox home ranges and population sizes in the Shiretoko National Park.

The present study did not always show that older feces resulted in lower success rates (Table 2). Although feces occurring in the field long time could have been exposed to sunlight and rain, and fecal DNA molecules could have been fragmented, the result of the present study indicates that older-looking feces sometimes included analyzable DNA as shown in Table 2.

On the other hand, the genotyping success rates of some loci in the present study were lower than those in other previous studies (e.g. Frantz et al. 2003; Piggott et al. 2006), indicating the difficulty of genetic analysis using fecal samples. The genotyping reproducibility values $(53.5-88.4 \%$, Table 1) show the unavoidable risks for genotyping errors. However, usage of better loci for identification would provide more reasonable investigations in lower cost and lower possibility of overestimate of population sizes by genotyping errors. Microsatellite loci having alleles in longer fragment sizes lead lower success rates and reproducibility of PCR amplification than the loci having shorter alleles (e.g. Hummel et al. 1999; Nielsen et al. 1999; Wandeler et al. 2003). Frantzen et al. (1998) also reported that short PCR fragments (100-200 bp) are significantly suitable to fecal identification analysis compared to longer fragments. 
The present study, although some loci are in exceptions, also indicated that genotyping success rates and reproducibility likely correlated to average allele sizes (Table 1, Figs. 2a, b). Especially, because the higher genotyping reproducibility can bring us lower repeated times of genotyping, the improvement can decrease laboratory cost and time. It is reasonable to use loci that have smaller allele sizes to obtain more reliable results even if the fragment sizes were less than 100-200 bp.

Although the ideal methods were different from species to species, many transport and preservation methods were already reported for fecal non-invasive analysis. A simple drying transfer method by using silica beads was the best way in bear feces (Wasser et al. 1997). Preservation in DMSO/EDTA/Tris/salt solution was also effective in baboons (Papio cynocephalus ursinus) (Frantzen et al. 1998). The combination of GuSCN/Silica extraction method (Boom et al. 1990; Höss \& Pääbo 1993) and the $70 \%$ ethanol-storage method brought high genotyping success rates in the Eurasian badger Meles meles (Frantz et al. 2003). Thus these methods may also improve the genotyping success rate. It could be more effective to develop the non-invasive method by improving the transportation and preservation methods and combination with the traditional field methods.

\section{References}

Banks, S. C., Piggott, M. P., Hansen, B. D., Robinson, N. A. and Taylor, A. C. 2002. Wombat coprogenetics: enumerationg a common wombat population by analysis of faecal DNA. Australian Journal of Zoology 50: 193-204.

Bellemain, E., Swenson, J. E., Tallmon, D., Brunberg, S. and Taberlet, P. 2005. Estimating population size of elusive animals with DNA from hunter-collected feces: comparing four methods for brown bears. Conservation Biology 19: 150-161.

Birky, C. W., Fuerst, P. and Maruyama, T. 1989. Organelle gene diversity under migration, mutation, and Drift: equilibrium expectations, approach to equilibrium, effects of heteroplasmic cells, and comparison to nuclear genes. Genetics 121: 613-627.

Boom, R., Sol, C. J. A. and Salimans, M. M. M. 1990. Rapid and simple method for purification of nucleic-acids. Journal of Clinical Microbiology 28: 495-503.

Flagstad, Ø., Hedmark, E., Landa, A., Brøseth, H., Persson, J., Andersen, R., Segerström, P. and Ellegren, H. 2004. Colonization history and noninvasive monitoring of a re-established wolvarine population. Conservation Biology 18: 676-688.

Frantz, A. C., Pope, L. C., Carpenter, P. J., Roper, T. J., Wilson, G. J. and Delahay, R. J. 2003. Reliable microsatellite genotyping og the Eurasian badger (Meles meles) using faecal DNA. Molecular Ecology 12: 1649-1661.

Frantzen, M. A. J., Silk, J. B., Ferguson, J. W. H., Wayne, R. K. and Kohn, M. H. 1998. Empirical evaluation of preservation methods for faecal DNA. Molecular Ecology 7: 1423-1428.

Holmes, N. G., Humphreys, S. J., Binns, M. M., Holliman, A., Curtis,
R., Mellersh, C. S. and Sampson, I. 1993. Isolation and characterisation of microsatellites from the canine genome. Animal Genetics 24: 289-292.

Höss, M. and Pääbo, S. 1993. DNA extraction from Pleistocene bones by a silica-based purification method. Nucleic Acids Reserch 21: 3913-3914.

Hummel, S., Schultes, T., Bramanti, B. and Herrmann, B. 1999. Ancient DNA profiling by megaplex amplifications. Electophoresis 20: 1717-1721.

Lucchini, V., Fabbri, E., Marucco, F., Ricchi, S., Biotani, L. and Randi, E. 2002. Noninvasive molecular tracking of colonizing wolf (Canis lupus) packs in the western Italian Alps. Molecular Ecology 11: 857-868.

Macdonald, D. W. 1979. 'Helper' in fox society. Nature 282: 69-71.

Mills, L., Citta, J., Lair, K., Schwartz, M. and Tallmon, D. 2000. Estimating animal abundance using non-invasive DNA sampling: promise and pitfalls. Ecological Applications 10: 283-294.

Nielsen, E. E., Hansen, M. M. and Loeschcke, V. 1999. Analysis of DNA from old scale samples: technical aspects, applications and perspectives for conservation. Hereditas 130: 265-276.

Nonaka, N., Tsukada, H., Abe, N., Oku, Y. and Kamiya, M. 1998. Monitoring of Echinococcus multilocularis infection in red foxes in Shiretoko, Japan, by coproantigen detection. Parasitology 117: 193-200.

Oku, Y. and Kamiya, M. 2003. Progress of Medical Parasitology. In (M. Otsuru, S. Kamegai and S. Hayashi, eds.) Progress of Medical Parasitology, pp. 293-318. Meguro Parasitological Museum, Tokyo (in Japanese).

Ostrander, E. A., Sprague, G. F. and Rine, J. 1993. Identification and characterization of dinucleotide repeat (CA) $n$ markers for genetic mapping in dog. Genomics 16: 207-213.

Piggott, M. P., Banks, S. C., Stone, N., Banffy, C. and Taylor, A. C. 2006. Estimating population size of endangered brush-tailed rock-wallaby (Petrogale penicillata) colonies using faecal DNA. Molecular Ecology 15: 81-91.

Putranto, H. D., Kusuda, S., Ito, T., Terada, M., Inagaki, K. and Doi, O. 2007. Reproductive cyclicuty based on fecal steroid hormones and behaviors in Sumatran tigers, Panthera tigris sumatrae. Japanese Society of Zoo and Wildlife Medicine 112: 111-115.

Shimatani, Y., Takeshita, T., Tatsuzawa, S., Ikeda, T. and Masuda, R. 2008. Genetic identification of mammalian carnivore spesies in the Kushiro wetland, eastern Hokkaido, Japan, by analysis of fecal DNA. Zoological Science 25: 714-720.

Shimatani, Y., Takeshita, T., Tatsuzawa, S., Ikeda, T. and Masuda, R. 2010. Sex determination and individual identification of American minks (Neovison vison) on Hokkaido, northern Japan, using fecal DNA analysis. Zoological Science 27: 243-247.

Suzuki, N., Ikeda, T. and Okano, M. 1983. The diversification of breeding form of the red fox (Vulpes vulpes) in Hokkaido. Mammalian Science 47: 1-12 (in Japanese).

Tsukada, H. 1997a. A division between foraging range and territory related to food distribution in the red fox. Journal of Ethology 15: $27-37$.

Tsukada H. 1997b. External measurements, breeding season, littler size, survival rate, and food habits of red foxes (Vulpes vulpes schrencki) in the Shiretoko National Park. Bull Shiretoko Mus 18: 35-44 (in Japanese with English summary).

Tsukada, H. 1997c. Acquisition of food begging behavior by red foxes in the Shiretoko National Park, Hokkaido, Japan. Mammal Study 22: 71-80.

Tsukada, H. and Nonaka, N. 1996. Foraging behavior of the red foxes Vulpes vulpes schrencki utilizing human food in the Shiretoko National Park, Hokkaido. Mammal Study 21: 137-151. 
Tsukada, H., Okada, H., Yamanaka, M., Nonaka, N. and Oku, Y. 1999. The spreading of sarcoptic mange among red foxes Vulpes vulpes and its impact on the local fox population in Shiretoko Peninsula, Hokkaido, Japan. Mammalian Science 39: 247-256 (in Japanese with English absract).

Uraguchi, K. 2008. Epidemiology and ecology of the red fox. In (N. Takatsuki and J. Yamagiwa, eds.) Mammalogy in Japan, pp. 149171. University of Tokyo Press, Tokyo (in Japanese).

Valière, N. 2002. GIMLET: a computer program for analyzing genetic individual identification data. Molecular Ecology Notes 2: 377-379.

Wandeler, P. and Funk, S. M. 2006. Short microsatellite DNA markers for the red fox (Vulpes vulpes). Molecular Ecology Notes 6: 98 100.

Wandeler, P., Smith, S., Morin, P. A., Pettifor, R. A. and Funk, S. M. 2003. Petterns of nuclear DNA degeneration over time-a case study in historic teeth samples. Molecular Ecology 12: 10871093.

Wasser, S. K., Houston, C. S., Koehler, G. M., Cadd, G. G. and Fain, S. R. 1997. Techniques for application of faecal DNA methods to field studies of Ursids. Molecular Ecology 6: 1091-1097.

Received 8 March 2010. Accepted 28 May 2010. 